\title{
Two Microliths from Javanese Wadjak Man
}

\author{
P. STORM \\ Collection Dubois \\ National Museum of Natural History \\ Leiden, The Netherlands
}

\begin{abstract}
Recently, during a restudy of the fragmentary bone material of the Wadjak site two microliths were discovered. A description of these artefacts is given. A discussion is presented in the light of other Holocene prehistoric sites from Java, a supposed linkage between Wadjak Man and the Pacitanian, the fauna and suggestions about the age of the Wadjak site. These new finds fit with the view of Wadjak Man as Modern Man ("Proto Javanese"), found in association with the subrecent fauna from Java.
\end{abstract}

Key Words Java, Wadjak Man, Subrecent Fauna, Microliths

\section{Introduction}

In $1888 \mathrm{Mr}$. B.D. Van RIETSCHOTEN, in a search for marble, discovered a fossilized human skull in a rockshelter, nowadays well known as the Wadjak site (Van RIETSCHOTEN, 1888; DUBOIS 1889, 1922; Plate 1). The Wadjak site is located on a mountain slope in Southwest Java, south of Mount Willis near the village of Wadjak (present day: Wajak), (DUBOIS, 1922; AZIZ and De VOS, 1989). The human skull was sent to DUBOIS who, attracted by this find, visited the site in 1890 and found fragments of a second fossilized human skull, postcranial skeleton elements and fossil mammal bones.

The first skull was indicated as W-I and the second as W-II. These two skulls became well known after their description as "Froto-Australians" (DUBOIS, 1922) and their suggested link with Pithecanthropus and the Ngandong hominids (OPPENOORTH, 1932). From the moment that KEITH (1936) included them in his theory about the origin of modern man, they played an important role in the setting up of hypotheses and models about (local) evolution in Java and migration from Southeast Asia to Australia (WEIDENREICH, 1945; COON, 1963; JACOB, 1967; WOLPOFF et al., 1984), although other opinions have also been published, a link between Wadjak Man and Papuans (DUBOIS, 1889), Neandertal Man
(BRACE et al., 1971; SOEJONO, 1984), Mediterranean (PINKLEY, 1936), or Wadjak Man as an extinct form (KEITH, 1925).

The fauna associated with the Wadjak skulls is well known (DUBOIS, 1922; Van den BRINK, 1982). Based on the fauna and the morphology of the human skulls (DUBOIS, 1922; JACOB, 1967; SANTA LUCA, 1980; STORM, 1990b), the date could be considered as somewhere in the Late Pleistocene or Holocene.

According to DUBOIS (1922) no artefacts had been found in the Wadjak site. However, recently, during a restudy of the fragmentary material, collected by DUBOIS in 1890 at the Wadjak site and stored in the National Museum of Natural History (N.M.N.H.) in Leiden, two microliths were discovered. The purpose of this paper is to give a description of these artefacts and to discuss them in their wider context, and in the light of a supposed link between Wadjak Man and the Pacitanian Culture (BARTSTRA, 1984a, b, 1987; SÉMAH et al., 1990).

\section{Two Microliths from the Wadjak Site}

Wadjak Artefact 1 (W-A-1)

A small blade, made from limestone (Fig. 1; Plates $2,4)$. The distal end is broken and there is some damage

Received December 18, 1991 


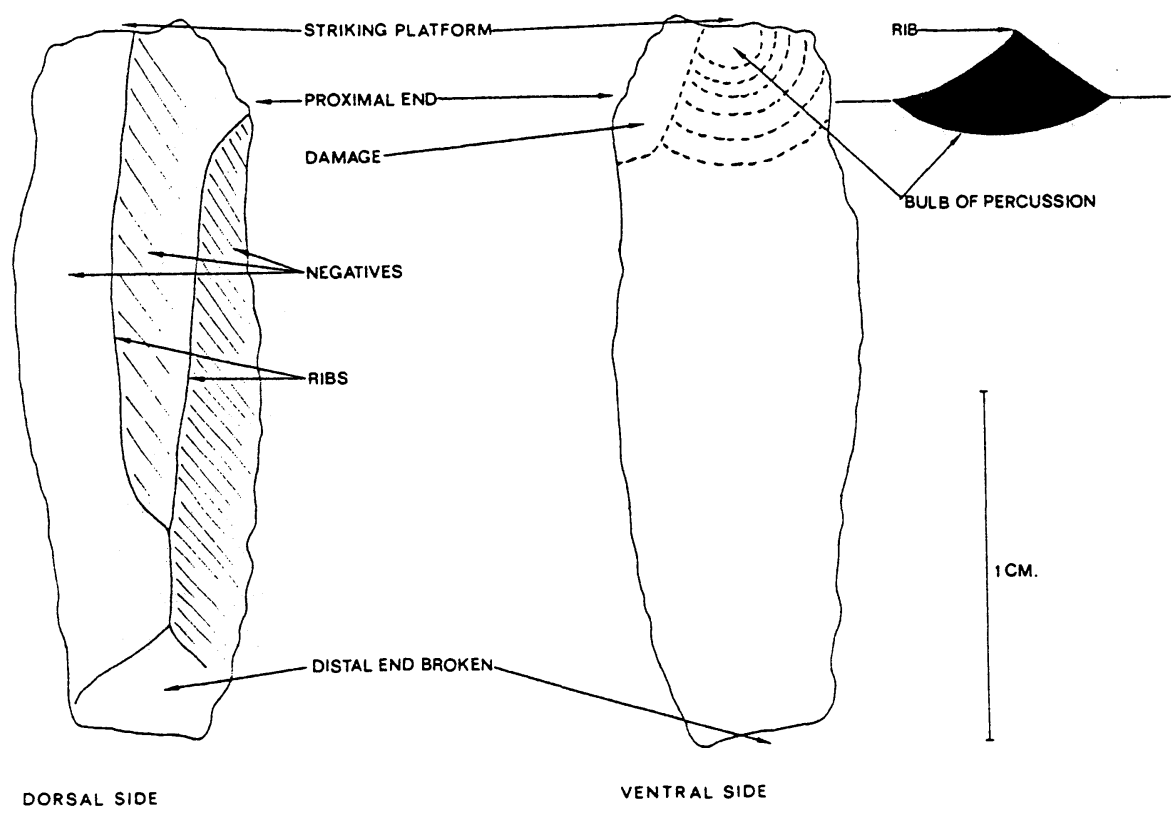

Fig. 1. Artefact W-A-1.

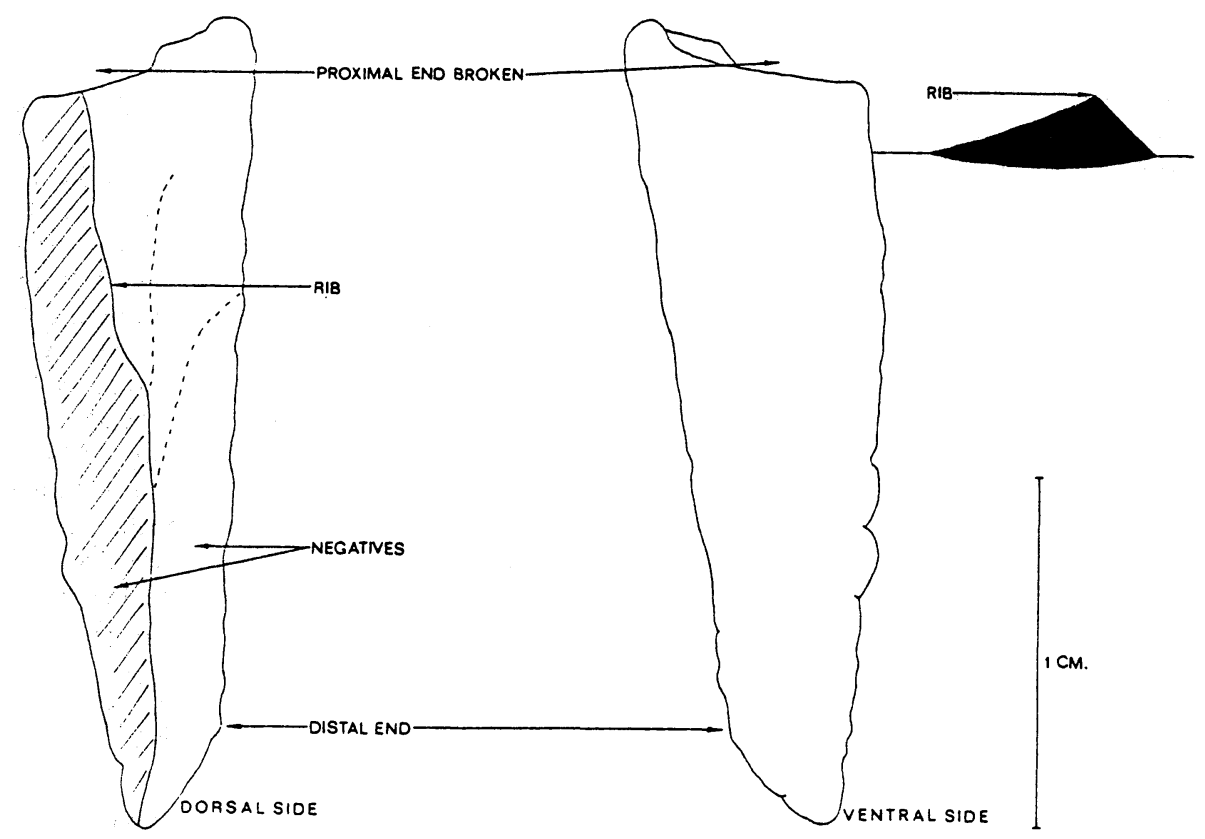

Fig. 2. Artefact W-A-2. 
at the proximal end. The shape of the body is elongated with parallel sides. Present are the bulb of percussion and the striking platform. The dorsal side has two parallel ribs (three negatives) and there is erosion at this surface. The ventral side is flat, but also at this surface there is erosion. There is no retouch.

Measurements of W-A-1:

Maximum length : $20.6 \mathrm{~mm}$

Maximum breadth : $6.9 \mathrm{~mm}$

Maximum thickness: $2.6 \mathrm{~mm}$

\section{Wadjak Artefact 2 (W-A-2)}

A small blade (possibly a point), made from limestone (Fig. 2; Plates 3, 5), which is in a bad condition. Proximal and distal ends are both broken, or are the result of intentional breakage. The ventral side is flat. On the dorsal side one can recognize one rib but possibly there were three ribs (parallel to the lateral sides). Ribs are difficult to recognize because there is edge damage (or retouch) on the dorsal side.

Measurements of W-A-2:

Maximum length $: 23.3 \mathrm{~mm}$

Maximum breadth : $6.5 \mathrm{~mm}$

Maximum thickness: $2.4 \mathrm{~mm}$

\section{Lithic and Bone Artefacts from Holocene Sites in Java}

Sampoeng is at this moment the best described site in Java, dating from the Mesolithic/Neolithic period. This site is located one mile South of Sampoeng, Ponorogo, East Java and well known for its bone tools. The first publication of the Sampoeng site (nowadays: Sampung; also called the Guwo Lowo; Guwo = cave and Lowo = bat) was given by Van ES in 1929, who discovered the site in 1926. A more extensive description was given by Van STEIN CALLENFELS in 1932, who worked on this site from 1928 till 1930. Information on the fauna was given by DAMMERMAN $(1932,1934)$. The human remains have been described by MIJSBERG (1932) and JACOB (1967).

In fact there is a great variability of artefacts and tools found in the Sampoeng site (Van STEIN CALLENFELS, 1932). ERDBRINK (1954) has discussed the Mesolithic/Neolithic status of the site. DAMMERMAN (1934) remarked that the exact place where each prehistoric implement or human material was found, had been ascertained with regard to depth as well as to the horizontal position. In the Sampoeng site four layers have been "recognized"' and the next overview can be given of the material found in the different layers (based on Van STEIN CALLENFELS, 1932):

Layer A: Roughly between 0 and $1.2 \mathrm{~m}$ deep, pottery fragments, polished stone adzes, some bronze objects and human remains.

Layer B: Roughly between 1.2 and $2.2 \mathrm{~m}$ deep, spatulas and points often made from antler; daggers and harpoons, grinding stones and hollowed stone basins (with and without traces of red clay), human remains.

Layer C: Roughly between 2.2 and $3.0 \mathrm{~m}$ deep, flint arrow-points, grinding stones, pottery fragments, human remains.

Layer D: Roughly between 3.0 and $3.6 \mathrm{~m}$ deep, arrow point, bronze object and human remains.

According to Von KOENIGSWALD (1956a) the "bone culture" from Sampoeng is also found in other Javanese sites like: Bodjonegro and Sitobondo (excavated by Van HEEKEREN).

In 1937 ERDBRINK and KERKHOVEN discovered an archaeological site in West Java, halfway between the Pasir (hill) Tjilawang and the hamlet of Tondjong, which ERDBRINK $(1943,1954)$ attributed to the "Mesolithic Sampoeng culture". In this site, the "Cave of Panoembangan", three distinct levels could be distinguished, fossilized remains of animals were found in the northern part of the cave, together with five flint implements. One flint implement was found in the southern part.

ERDBRINK (1954) further remarked that, apart from the mentioned site, a small open-air site nearby (also located on the Panoembangan tea estate) seems to be the only indication of the presence of remains of Mesolithic people in West Java. ERDBRINK (1954) also reported a locality, discovered in 1936 by Von KOENIGSWALD, which could be from the Mesolithic period. A rockshelter, located on the eastern side of a hill, the Gunung Tjantelan, close to the village of Punung. They found a large number of flint flakes, some hammerstones, several arrowpoints (with a rounded base), scrapers, bones, pierced shells of snails (used as components of necklaces) and a few isolated human teeth.

BARTSTRA and BASOEKI (1979) reported a new stone age site from East Java, which they thought was from a Post Pleistocene period, either Mesolithic or Neolithic, although the dating was not certain. The site is located near a small village (Pucanganak), about 12 $\mathrm{km}$ west of the town of Trenggalek. They found a number of rectangular axe-like objects, scrapers and borers.

SUBAGUS (1979) reported on an "Obsidian Industry in Leles", from West Java. According to him the flakeblade tradition originated in the Palaeolithic period during the Pleistocene era (Ngandong, Pacitan, Sangiran) and continued to develop in the Epipalaeolithic period. About this industry SUBAGUS remarked that it includes nuclei, blades and waste.

DUBOIS started his excavations on June 9 in 1890 on 
the Wadjak site. In the period from October 1890 to December 1890 excavations were carried out in the Hoekgrot site (other names sometimes used are: "'Hukgrot", “Eastern [Corner] Cave", "Goea Lawa”, "Kovher Cave", or "Nieuwe Grot"). Parts of the cranium and mandible of a domesticated dog from the Hoekgrot site are described by BRONGERSMA (1941). DUBOIS (1922) mentioned the red painted human material from this site. The first description of the human remains was given by NELSON $(1988,1989)$ and later, when more human material was found in the collection of the N.M.N.H. in Leiden, a second description by STORM (1990a). The Hoekgrot site is interesting, not only for the red painted human skeleton but also for faunal remains (see Table 2), artefacts (bone implements and pottery fragments, Table 1), signs of cultural activities and a domesticated dog.

There is a note from one of DUBOIS' assistants, which is dated December 30,1890, in which it is reported that two days before, nothing more than a few human molars had been found and that the exit of the cave was $6.10 \mathrm{~m}$ deep. This could be an indication that the excavations were thoroughly done and that everything found was collected. Another indication for this last statement is the fact that a map with a grid system of the excavations of the Hoekgrot site was made (see: AZIZ and De VOS, 1989).

In the Hoekgrot site clear indicators of human activities were found; four different types of bone tools (total number is 7); large and small spatula's; large and small bone points. Further fragments of pottery, charcoal and burnt bones, animal bones with cut- and chop-marks and a nearly complete red painted human skeleton were found. It is possible that these prehistoric people practised activities like removing the flesh from the human body, and then painting the skeleton parts red as part of their mortuary ritual.

Another site excavated by DUBOIS in 1890 is the Goea Djimbe site. This site is situated near Redjobangan, about $10 \mathrm{~km}$ West of Blitar in East Java (Van den BRINK, 1983; BURGERS, 1988). Some of the human material from this site was described by NELSON (1988, 1989). Data on the fauna have been published by BRONGERSMA (1941) and HOOIJER (1962), and are described by Van den BRINK (1983). The bone tools have been preliminarily described by BURGERS (1988). A more extensive description and discussion of these artefacts and tools is given by STORM (1990b).

There are not many notes from this site and it is not possible to give a reconstruction of the site and excavation. It is believed that the layer at three metre (where bone tools and both human and fauna remains have been found) belongs to a much older period than the layer at a depth of two metre. Five different kinds of artefacts have been found in the Goea Djimbe site, all made from animal remains. Chisel and spatula like artefacts could have been used for the working of wood or as a scraper

Table 1. Main groups of artefacts and tools from different Javanese sites

\begin{tabular}{lcccc}
\hline & Wadjak* & $\begin{array}{c}\text { Goea } \\
\text { Djimbe* }\end{array}$ & Hoekgrot* Sampoeng \\
\hline Bone tools & - & + & + & + \\
Ornaments (shells) & - & - & - & + \\
Stone artefacts & + & - & - & + \\
Flint arrowpoints & - & - & - & + \\
Polish. stone adzes & - & - & - & + \\
Grinding stones & - & - & - & + \\
Pottery & - & - & + & + \\
Bronze & - & - & - & + \\
\hline
\end{tabular}

Explanation of symbols:

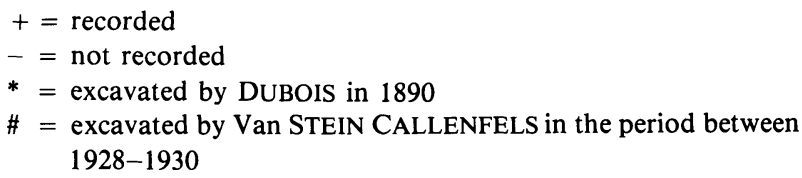


Table 2. Mammalia of different Holocene Javanese sites

\begin{tabular}{|c|c|c|c|c|}
\hline $\begin{array}{l}\text { Species/ } \\
\text { (Groups) }\end{array}$ & Hoekgrot* & G.Djimbe* & Wadjak* & Sampoeng $\#$ \\
\hline \multicolumn{5}{|l|}{ Primates } \\
\hline$N$. coucang & + & + & - & + \\
\hline M. fascicularis & + & + & - & + \\
\hline$T$. cristatus & + & + & + & + \\
\hline H. sapiens & + & + & + & + \\
\hline (Cercopith.) & + & + & + & + \\
\hline \multicolumn{5}{|l|}{ Carnivora } \\
\hline P. hermaphr. & + & - & - & + \\
\hline Lutrea cinera & - & - & - & + \\
\hline M. flavigula & - & + & - & - \\
\hline P. tigris & - & - & + & + \\
\hline$F$. bengalensis & - & - & - & + \\
\hline A rctogalidia & - & + & - & - \\
\hline Cuon javanicus & - & + & - & + \\
\hline C. familiaris & + & - & - & - \\
\hline (Indet.) & + & + & + & + \\
\hline \multicolumn{5}{|l|}{ Rodentia } \\
\hline A. brachyurus & + & + & + & + \\
\hline Sciurus notatus & - & - & + & + \\
\hline Ratufa bicolor & - & + & - & + \\
\hline$P$. petaurista & - & - & - & + \\
\hline K. sodyi & - & + & - & - \\
\hline L. sabanus & - & + & - & + \\
\hline$R$. tiomanicus & - & - & + & - \\
\hline R. rattus & - & - & - & + \\
\hline (Indet.) & + & + & + & + \\
\hline \multicolumn{5}{|l|}{ Proboscidae } \\
\hline E. maximus & + & - & - & + \\
\hline \multicolumn{5}{|l|}{ Perissodactyla } \\
\hline$R$. sondaicus & + & + & + & + \\
\hline Tapirus indicus & - & + & + & - \\
\hline \multicolumn{5}{|l|}{ Artiodactyla } \\
\hline Sus scrofa & - & + & + & + \\
\hline Sus verrucosus & - & + & - & - \\
\hline$T$. javanicus & + & + & - & + \\
\hline M. muntjac & + & + & + & + \\
\hline R. timorensis & + & + & + & + \\
\hline C. sumatraensis & - & + & - & - \\
\hline Bos sondaicus & - & $+?$ & $+?$ & + \\
\hline B. bubalus & - & $+?$ & $+?$ & + \\
\hline (Bovinae) & + & + & + & + \\
\hline (Suidae) & + & + & + & + \\
\hline \multicolumn{5}{|l|}{ Chiroptera } \\
\hline C. sphinx & - & + & - & - \\
\hline $\begin{array}{l}\text { Ro. amplexic. } \\
\text { Dermoptera }\end{array}$ & - & + & - & - \\
\hline Cyn. sp. & - & + & - & - \\
\hline
\end{tabular}

\footnotetext{
Explanation of symbols

$+=$ recorded

$-=$ not recorded

$?=$ uncertain

* = excavated by DUBOIS in 1890

$\#$ = excavated by Van STEIN CALLENFELS in the period between $1928-1930$
} 
for hides. Bone points and worked pig canines could have been used as drills, the worked canines may also have been used as ornaments.

According to KLEIWEG de ZWAAN (1943) several places have been found in the area of Bandung in which small artefacts have been found,i.e., north of Bandung: Lembang, Tjakidang, Pagermanoek, Pakar, Negla, Lebaksioe, Tjilimoes, Tjiharalang, Bodjongkoning and Nagreg; southeast of Bandung: Paseh and Patjet; south of Bandung: Koelalet and Pameumpeuk; west of Bandung: Tjililin and Tjilalem. This could be an indication that groups of peoples, who produced microliths, were once widespread on the island of Java.

Artefacts and tools found in the Sampoeng site have also been found in the sites Wadjak, Goea Djimbe and Hoekgrot (Table 1). In addition the same subrecent fauna has been found in all four sites (Table 2). This is the main reason for believing that the Wadjak, Goea Djimbe and Hoekgrot sites could belong to the same period as the Sampoeng site, Mesolithic and/or Neolithic. The richness of the Sampoeng site is striking in comparison with the other three sites: Wadjak, Hoekgrot and Goea Djimbe. Surprising are the finds of bronze objects in the Sampoeng site. The bronze objects can perhaps be seen as a later distortion since they are not as numerous as other artefacts (associated with the Mesolithic/Neolithic) and most of the bronze objects are found in the upper layer and only one in the lower layer D.

The largest part of the remains from the Sampoeng site consists of pottery fragments, artefacts made from animal remains, stone arrow points and stones for grinding. Most of the pottery fragments and artefacts made from animal remains have been found in the upper deposits, while most of the stone arrow points have been found in the lower deposits. Because of this it is possible that the upper layers (A and B) are Neolithic and the lower layers $(C$ and the border $B / C)$ are Mesolithic.

The pottery fragments found in Hoekgrot indicate that this site is probably Neolithic. Since two microliths have been found in the Wadjak site, and no Neolithic indicators, it is suggested that this site is Mesolithic. It is important to realize that if there had been bone tools in the Wadjak site, they would have been collected by DUBOIS, because he collected every bone fragment. Those suggestions appear to be in agreement with the observation made by Van ES (1929) that in the Sampoeng cave the bone culture was preceded by one that made greater use of stone.

When considering the bone artefacts from the sites Sampoeng, Hoekgrot and Goea Djimbe the question arises, what is generally known about bone tools from this region and what can be deduced from these tools about the age of the sites. Von KOENIGSWALD (1956a) remarked that similar bone tools, to those found in the Sampoeng site have also been found in other areas of Java, Bodjonegro, Sitobondo, and from more remote places like Malakka and Indo-China. Bone tools have been widely used in Australia (DORTCH, 1984) and Europe (OAKLEY, 1975) for thousands of years. Consequently, it is highly probable that bone tools have been used for a very long time during the Palaeolithic, Mesolithic and Neolithic in Java. The typology of the bone tools themselves do not give much clarity about the exact age of the prehistoric Javanese sites.

\section{The Linkage of Wadjak Man with the Pacitanian}

On October 4th 1935 Von KOENIGSWALD (1936a, b) and TWEEDIE found primitive-looking stone artefacts in the bed of the Baksoko, a small river near the South coast of Central Java. Von KOENIGSWALD called the culture Pacitanian after the nearby village, Pacitan. He considered Homo erectus as the maker of this culture. This he based on the fact that at Punung, a village near Pacitan, fossil mammals were found in fissure fillings (for example Stegodon). He assumed that they had the same age as the fossils from Trinil, where Homo erectus had been found. Following Von KOENIGSWALD, MOVIUS (1948: 408) and Van HEEKEREN (1972: 43) also attributed the Pacitanian to Homo erectus, and placed this culture in the Middle Pleistocene. However, BARTSTRA (1984a, b, 1987) placed the Pacitanian in the Late Pleistocene or Holocene and this author considered Wadjak Man (Homo sapiens) as the maker of this culture. BARTSTRA (1984b: 171) state:

"In fact, there is only one prehistoric hominid that is worthy of consideration as maker of the Patjitan tools, namely Wajak Man. The skulls of this hominid (found on the south coast of Java) had already been studied by DUBOIS before he made his finds in Trinil. Wajak Man is much younger than Java Man, and is also younger than Solo Man. Wajak Man is a subspecies of Homo sapiens, and is described as having Australoid affinities. He lived on Java in the last phases of the Pleistocene and at the beginning of the Holocene - the time from which the Patjitanian artifacts apparently originate."

In the same year BARTSTRA (1984a: 258) concluded: "The Pacitanian must be regarded as the Javanese variant of the so-called Hoabhinian in Southeast Asia; and Homo wadjakensis might be the manufacturer."

In 1987 (page 6) BARTSTRA remarked:

"Although this industry can still be called Palaeolithic, it is in my opinion very young, and it dates surely from the second half of the Upper Pleistocene (BARTSTRA, 
1984). This pacitanian should be associated with Homo sapiens (Wajak Man?) who inhabited Java at that time."

As recently as 1990 SÉMAH et al. remarked:

"According to G.J. BARTSTRA the Patjitanian tools are the work of the Wajak Man and are at the most 50,000 years of age."

That "Wadjak Man" is the (possible) tool-maker of the Pacitanian (BARTSTRA, 1984a, b, 1987; SÉMAH et $a l ., 1990)$ is only a suggestion. The Wadjak site and artefacts from Pacitanian have no relation. The two microliths from the Wadjak site are very different from the Pacitanian. The Pacitanian belongs to a widespread group of "chopper/chopping-tool industries" (BARTSTRA, 1976, 1987; BELLWOOD, 1985) which is indeed very different from the two small artefacts from the Wadjak site. Another problem is that some scientists view the Pacitanian as a local variant of the broadly defined Hoabinhian and that possibly a great many Pacitanian artefacts are in fact the result of natural processes (TATTERSALL et al., 1988).

\section{The Faunas of the Holocene Sites}

One of the fascinating aspects of the fauna (which is found in association with the human remains, artefacts and tools) from the above mentioned sites is the fact that it gives a picture of the original fauna of Java before the island was heavily populated by humans (Table 2 ). The Wadjak fauna can be interpreted as an open woodland fauna (De VOS, 1983) and coming from the mainland (SONDAAR, 1984). Some of the animals like Tapirus indicus, Elephas maximus, Cervus eldi, Cervus kuhlii and Capricornus sumatraensis are extinct in Java nowadays. An animal like Rhinoceros sondaicus is restricted to a reserve in West Java. It can be expected that the transition from the Mesolithic to the Neolithic period in Java has had its effect on the wild animals, because of vanishing woods and the introduction of domesticated animals.

In this respect the tapir (Tapirus indicus) is an interesting species. This animal needs a primary forest, which means that the species will disappear if this forest vanishes. Therefore one could expect that the tapir became extinct in Java at the moment when important changes in this forest took place. This could be the cultural change from a Mesolithic (hunting-gathering) way of life to a Neolithic subsistence pattern based on agriculture. LEINDERS et al. (1985: 169) remark in connection with the occurrence of the tapir in the Wadjak fauna that it "probably documents its last occurrence on Java." The tapir is found in the Wadjak and Goea Djimbe site, but not in the Hoekgrot site. This could be an indication that indeed the tapir became extinct in Java during the
Neolithic.

It is highly probable that in all 4 sites Wadjak, Goea Djimbe, Hoekgrot and Sampoeng people were responsible for the collection of the animal bone remains. There are several arguments to support this view. In the first place indications have been found for the presence of complete human bodies; cutmarks have been found on animal bones; burnt bone fragments, artefacts and remains of mollusca and fishes from the sea (the Hoekgrot site and Wadjak site are $9 \mathrm{~km}$ from the sea). In other words these fauna assemblages cannot be seen as natural, but selection by man must have played an important role in the bone accumulation.

The Wadjak and Hoekgrot site are probably not "hunting camps" because not many indications have been found of hunting activities, no arrow points, and no signs of the manufacturing and use of tools for butchering. It is striking that rockshelters, like Wadjak and Hoekgrot, being very close together, contain basically the same assemblage, the subrecent fauna in a fragmentary state, indications of complete human bodies, some artefacts, and distinct evidence of human activities. Taking this into consideration it is probable that the bone accumulation of the Wadjak and Hoekgrot site is the result of funeral deposition in a rockshelter.

\section{The Age of the Wadjak Site}

The age suggested for the Wadjak site ranges from Early Pleistocene (DUBOIS, 1922; SOEJONO, 1984); the border Pleistocene/Holocene (HOWELLS, 1964; JACOB, 1967; BARTSTRA, 1984b) to recently in the Holocene (Von KOENIGSWALD, 1956b; WOLPOFF et al., 1984; HABGOOD, 1989). Some scientists remarked that the date of the site must be left as undetermined (PINKLEY, 1936; Van den BRINK, 1982). For the Sampoeng site most researchers agree on a date within the Holocene. No real claims have been made for the other two sites, Hoekgrot and Goea Djimbe.

According to Van HEEKEREN (1975), in Indonesian prehistory, the epipalaeolithic period can be dated between 10,000 and 5,000 B.P. Van HEEKEREN further remarked that one of the characteristic of the epipaleolithic period is the occurrence of microlithic industries.

The present study indicates the following with regard to the Wadjak site:

- The human remains found are from modern man (Homo sapiens) and can be interpreted as "robust looking Javanese', (STORM, 1990b).

-The human remains have been found in association with the subrecent fauna from Java (Van den BRINK, 1982), in which the tapir is present. No domesticated animals have been found.

- Microliths have been found, and no indications of the Neolithic period (pottery remains). 
- No proof has been found for the evolutionary line, Ngandong $\rightarrow$ Wadjak $\rightarrow$ Australians, not in the palaeoanthropological, archaeological, nor palaeontological data (STORM, 1990b).

In the light of the foregoing information, a view of Wadjak Man emerges, in contrast to earlier opinions, as a "Proto-Javanese", possibly belonging to a once widespread group of prehistoric peoples, which manufactured microliths and lived by hunting and gathering. They used rockshelters for their funeral rites, just like nowadays (NOOY-PALM, 1989). If Van HEEKEREN (1975) is correct in his dating and interpretations, these inhabitants of Java lived somewhere in the Mesolithic period between 10,000 and 5,000 years B.P.

\section{Conclusion}

Since the discovery of the Wadjak skulls around 1890, one could only guess about the "Wadjak Culture", because no artefacts or tools were known from this site. Recently two microliths have been found among the fragmentary bone material. Two artefacts are not enough to draw extensive conclusions but can give an extra dimension to the discussion around the supposed link between the Wadjak fossils and the Pacitanian Culture, and help to place Wadjak Man in his wider context.

There is no reason to link Wadjak Man with the Pacitanian industry. There is no direct relation between the Wadjak site and the Baksoko river. The artefacts from both places are very different. In the Wadjak site microliths have been found, the Pacitanian has been described as a "chopping-chopper-tool industry".

Since no indicators have been found in the Wadjak site for the Neolithic period and two microliths have been found it could be suggested that this site can be dated in the Mesolithic period. The findings of the faunal remains of the Wadjak site, in which Tapirus indicus is present and no indicators are found of domesticated animals, and the opinion of the Wadjak hominids as modern Homo sapiens ("robust looking Javanese"), are in agreement with this view.

\section{Acknowledgements}

I am grateful to Dr. J. De VoS and R. Van ZELST (N.M.N.H., Leiden, the Netherlands) for their assistance during the study and their useful remarks. I also wishes to thank the following persons for their help and comments: Dr. C.E.S. ARPS (N.M.N.H., Leiden, the Netherlands), Dr. P.L. LOADER (Den Haag, the Netherlands), Drs. L.E. LOADER - Van den MUIJZENBERG (Den Haag, the Netherlands), Dr. P.Y. SONDAAR (Palaeontology, University of Utrecht), B.N. STORM (Hoogeveen, the Netherlands), Dr. C.B. STRINGER (Department of Palaeontology, the Natural History Museum, London U.K.), B.C. Van der HOUT
(Den Haag, the Netherlands), Drs. L. VERHART (R.M.O. Leiden, the Netherlands).

\section{抄録}

ワジャク遺跡から発見された細石器 2 点

\section{P. STORM}

ワジャク遺跡出土の断片的骨資料を再研究してい る際に発見された 2 点の細石器を記載した。 そして, 以下の諸点につき議論がなされた.すなわち, ワジャ ク遺跡と他のジャワ完新世遺跡との比較, ワジャク 人とパチタニアン文化および共伴動物群との関連性, そしてワジャク遺跡の年代である.これらの知見か らワジャク人は半化石動物群と同時代の現生人類 (プロトジャワニーズ）であることがわかった。

\section{References}

AZIZ, F. and J. DE VOS, 1989: Rediscovery of the Wadjak Site (Java, Indonesia). J. Anthrop. Soc. Nippon, 97: 133-144.

BARTSTRA, G.J., 1976: Contributions to the Study of the Paleolithic Patjitan Culture Java, Indonesia. E.J. Brill, Leiden.

BARTSTRA, G.J., 1984a: Dating the Pacitanian: Some thoughts. Cour. Forsch. Inst. Senckenberg, 69: 253-258.

BARTSTRA, G.J., 1984b: Some remarks upon fossil man from Java, his age and his tools. In: Van der VELDE (ed.) Prehistoric Indonesia a Reader. Foris Publications, Dordrecht, pp. 163-177.

BARTSTRA, G.J., 1987: Late Homo erectus or Ngandong man of Java. Palaeohistoria acta et communicationes instituti bioarchaeologici universitatis groninganae 29.

BARTSTRA, G.J. and BASOEKI, 1979: A new stone age site in East-Java: an announcement. Mod. Quatern. Res. SE Asia, 5: 89-90.

BELLWOOD, P., 1985: Prehistory of the Indo-Malaysian Archipelago. Academic Press, Sydney.

BRACE, C.L., H. NELSON and N. KORN, 1971: Atlas of Fossil Man. Holt, Rinehart and Winston, New York.

BRONGERSMA, L.D., 1941: On the remains of carnivora from cave deposits in Java and Sumatra with notes on recent specimens I. Zool. Meded., 23: 114-148.

BURGERS, J.G. Ph., 1988: Ngalau Lida Ajar (Sumatra) en Goea Djimbe (Java) palaeoecologisch onderzoek aan twee grotten fauna's van Indonesie. (Intern report, not intended for publication). 
COON, C.S., 1963: The Origin of Races. Jonathan Cape, London.

DAMMERMAN, K.W., 1932: Donneé provisoire des mammiféres dans la grotte de Sampung. Hommage, Premier Congrés des Préhistoriens d'Extrême-Orient à Hanoi. Société Royale des Arts et des Sciences de Batavia, 30-31.

DAMMERMAN, K.W., 1934: On prehistoric mammals from the Sampoeng cave, central Java. Treubia Vol. XIV, Livr. 4.

De VOS, J., 1983: The Pongo faunas from Java and Sumatra and their significance for biostratigraphical and paleoecological interpretations. Proceedings B, 86: $417-425$.

DORTCH, C., 1984: Devil's Lair, A Study in Prehistory. Western Australian Museum.

DUBOIS, E., 1889: Nat. Tijd. Ned-Ind., 10: 209-211.

DUBOIS, E., 1922: The Proto-Australian Fossil Man of Wadjak, Java. Koninklijke Akademie van Wetenschappen, Amsterdam, 23: 1013-1051.

ERDBRINK, D.P., 1943: Een vindplaats van Mesolitische cultuur in West-Java. Cultureel Indie, vijfde jaargang: 124-127.

ERDBRINK, D.P., 1954: Mesolithic remains of the sempoeng stage in Java: some remarks and additions. Southwest. J. Anthropol., 10: 294-303.

HABGOOD, P.J., 1989: The Origin of Anatomically Modern Humans in Australasia. In: MELlARS, P. and STRINGER, C. (eds.) The Human Revolution: Behavioural and Biological Perspectives on the Origins of Modern Humans. Princeton University Press, pp. 245-273.

HOOIJER, D.A., 1962: Quaternary Langurs and Macaques from the Malay Archipelago. Zoologische Verhandelingen, 55: 1-64.

HOWELLS, W., 1964: Mensheid in wording, het verhaal van de menselijke evolutie. C. de BOER Jr./Paul BRAND, Hilversum.

JACOB, T., 1967: Some Problems Pertaining to the Racial History of the Indonesian Region. Drukkerij Neerlandia, Utrecht.

KEITH, A., 1925: The Antiquity of Man. Williams and Norgate, London.

KEITH, A., 1936: History from caves: A new theory of the origin of modern races of mankind. (British Speleological Association). First Speleological Conference.

KLEIWEG de ZWAAN, J., 1943: De oudste mensheid van de Indische Archipel. N.V. Servire, Den Haag.

LEINDERS, J.J.M., F. AZIZ, P.Y. SONDAR and J. de VOS, 1985: The age of the hominid-bearing deposits of Java: state of the art. Geologie en Mijnbouw, 64: 167-173.

MIJSBERG, W.A., 1932: Recherches sur les restes humains trouvés dans les fouilles de l'abris-sous-roche du Guwa Lawa à Sampoeng et des sites préhistoriques à Bodjonegoro (Java). Hommage, Premier Congrés des Préhistoriens d'Extrême-Orient à Hanoi. Société Royale des Arts et des Sciences de Batavia, pp. 39-54.

MOVIUS, H.L. Jr., 1948: The Lower Palaeolithic cultures of Southern and Eastern Asia. Trans. Amer. Phil. Soc., 38: 329-420.

NELSON, A., 1988: Newly Described Material from the Dubois Collection: Human Skeletal Material from Goea Lawa Hoekgrot, Goea Ketjil, Goea Djimbe. (Internal report, not intended for publication).

NELSON, A., 1989: Newly described material from Wadjak, Java. 58th Annual Meeting of the American Association of Physical Anthropologists, San Diego, California.

NOOY-PALM, H., 1989: A Rock Grave as the Sa'dan Toraja's Final Resting-Place. In: SCHEFOLD et al. (eds.) Indonesia in Focus Ancient Traditions-Modern Times, pp. 98-109.

OAKLEY, K.P., 1975: Man the Tool-Maker. Trustees of the British Museum (Natural History), London.

OPPENOORTH, W.F.F., 1932: Ein neuer divulialer Urmensch von Java. Natur und Museum, 62: 269-280.

PINKLEY, G., 1936: The significance of Wadjak Man, A fossil Homo sapiens from Java. Peking Natural History Bulletin, 10: 183-200.

SANTA LUCA, A.P., 1980: The Ngandong Fossil Hominids. Department of Anthropology, Yale University.

SÉMAH, F., A.-M. SEMAH and T. DJUBIANTONO, 1990: Centre Culturel Francais De Bandung.

SOEJONO, R.P., 1984: Prehistoric Indonesia. In: van der VELDE (ed.) Prehistoric Indonesia a Reader. Foris Publications, Dordrecht, pp. 49-78.

SONDAAR, P.Y., 1984: Faunal evolution and the mammalian biostratigraphy of Java. Cour. Forsch. Senckenberg, 69: 219-235.

STORM, P., 1990a: Newly Described Neolithic Site from Java. The Archaeological Site Hoekgrot: Human Remains, Artifacts and the Subrecent Fauna of Java, pp. 1-120. (Doctoral manuscript, not intended for publication).

STORM, P., 1990b: Mesolithic and Neolithic sites from Java: human remains, artifacts and the subrecent fauna. Part I, the text: 1-172. Part II, the tables, figures and plates, pp. 1-84. (Doctoral manuscript, not intended for publication).

SUBAGUS, N.A., 1979: Obsidian industry in Leles, West Java; preliminary report. Mod. Quatern. Res. SE Asia, 5: 35-41.

TATTERSAll, I., E. DELSON and J.Van COUvering, 1988: Encyclopedia of Human Evolution and Prehistory. Garland (Vol. 768). 
Van den BRINK, L.M., 1982: On the mammal fauna of the Wajak Cave, Java (Indonesia). Mod. Quatern. Res. SE Asia, 7: 177-193.

Van den BRINK, L.M., 1983: On the vertebrate fauna of the Goea Djimbe Cave, West Java (Indonesia). (Internal report, not intended for publication).

Van ES, L.J.C., 1929: The prehistoric remains in Sampoeng cave residency of Ponorogo, Java. Fourth Pacific Science Congress, pp. 1-12.

Van HEEKEREN, H.R., 1972: The Stone Age of Indonesia. Verh. Kon. Inst. Taal-, Land- en Volkenkunde, 61, The Hague.

Van HEEKEREN, H.R., 1975: Chronology of the Indonesian prehistory. Mod. Quatern. Res. SE Asia, 1: 47-52.

Van RIETSCHOTEN, B.D., 1888: Nat. Tijd. Ned-Ind., 9: 346-347.

Van STEIN CALLENFELS, P.V., 1932: Note preliminaire sur les fouilles dans L'abri-sous-roche du Guwa Lawa a Sampung. Hommage, Premier Congrés des Préhistoriens d'Extrême-Orient à Hanoi, Société Royale des Arts et des Sciences de Batavia, pp. 16-29.
Von KoENIGSWALD, G.H.R., 1936a: Early Palaeolithic stone implements from Java. Bull. Raffles Mus. Singapore, 1: 52-60.

Von KOENIGSWALD, G.H.R., 1936b: Das Pleistocan Javas. Quartar, 2: 28-53.

Von KOENIGSWALD, G.H.R., 1956a: Speurtocht in de prehistorie Ontmoetingen met onze voorouders. De spieghel, Amsterdam.

Von KOENIGSWALD, G.H.R., 1956b: The geological age of Wadjak Man from Java. Proc. Kon. Ned. Akad. Wetensch. (B), 59: 455-457.

WEIDENREICH, F., 1945: The Keilor skull: A Wadjak type from Southeast Australia. Am. J. Phys. Anthropol., 3: 21-32.

WOLPOFF, M.H., WU XIN ZHI and A.G. THORNE, 1984: Modern Homo sapiens origins. A general theory of hominid evolution involving the fossil evidence from East Asia. In: SMITH, F.H. and F. SPENCER (eds.) The Origins of Modern Humans: A World Survey of the Fossil Evidence. Alan R. Liss., New York, pp. 411-483.

\section{P. STORM Collection Dubois}

National Museum of Natural History

Leiden, The Netherlands 


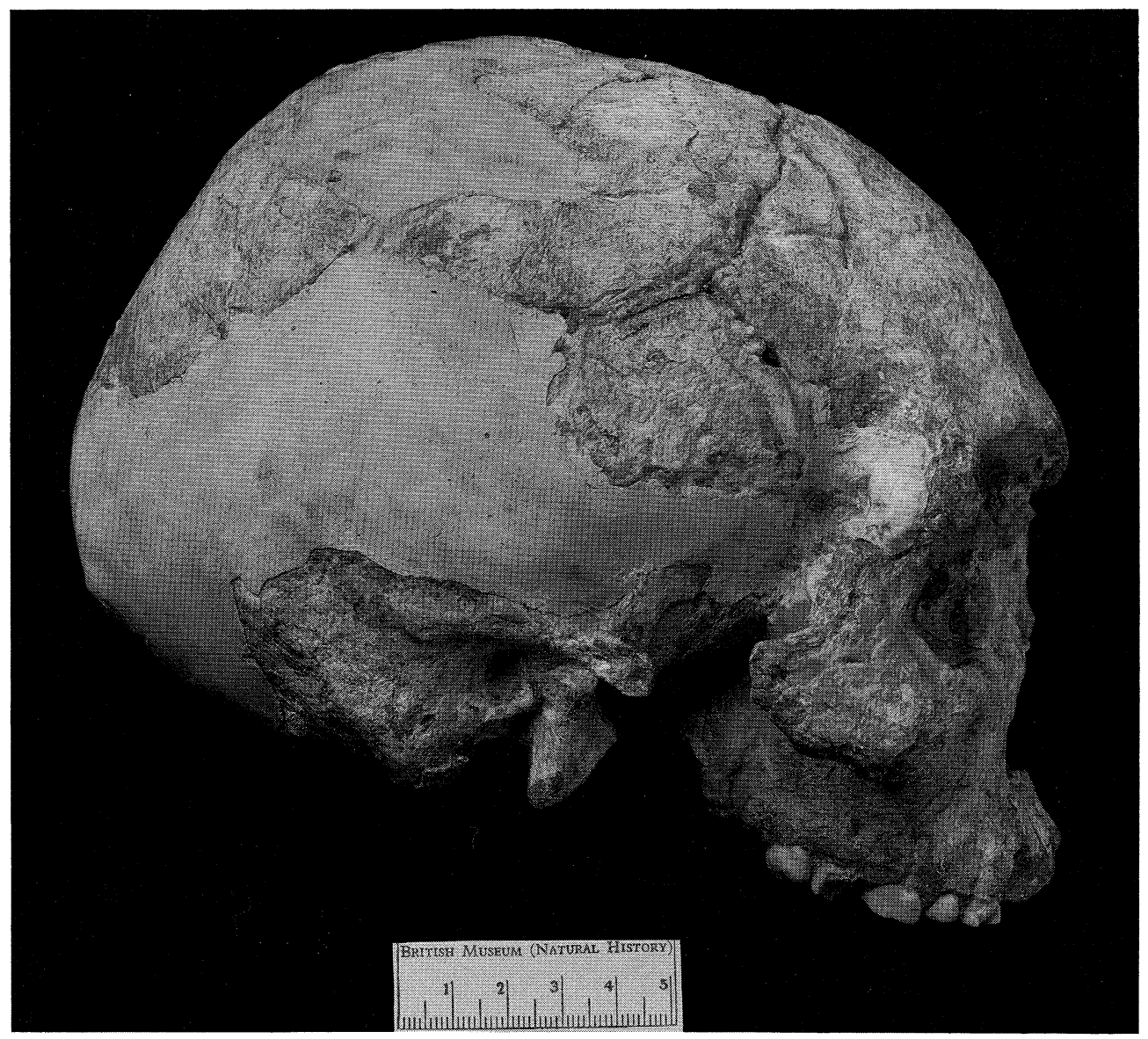

Plate 1. The Wadjak-I skull (seen from norma lateralis dextra).

(Photograph taken by The Natural History Museum, London, U.K.) 


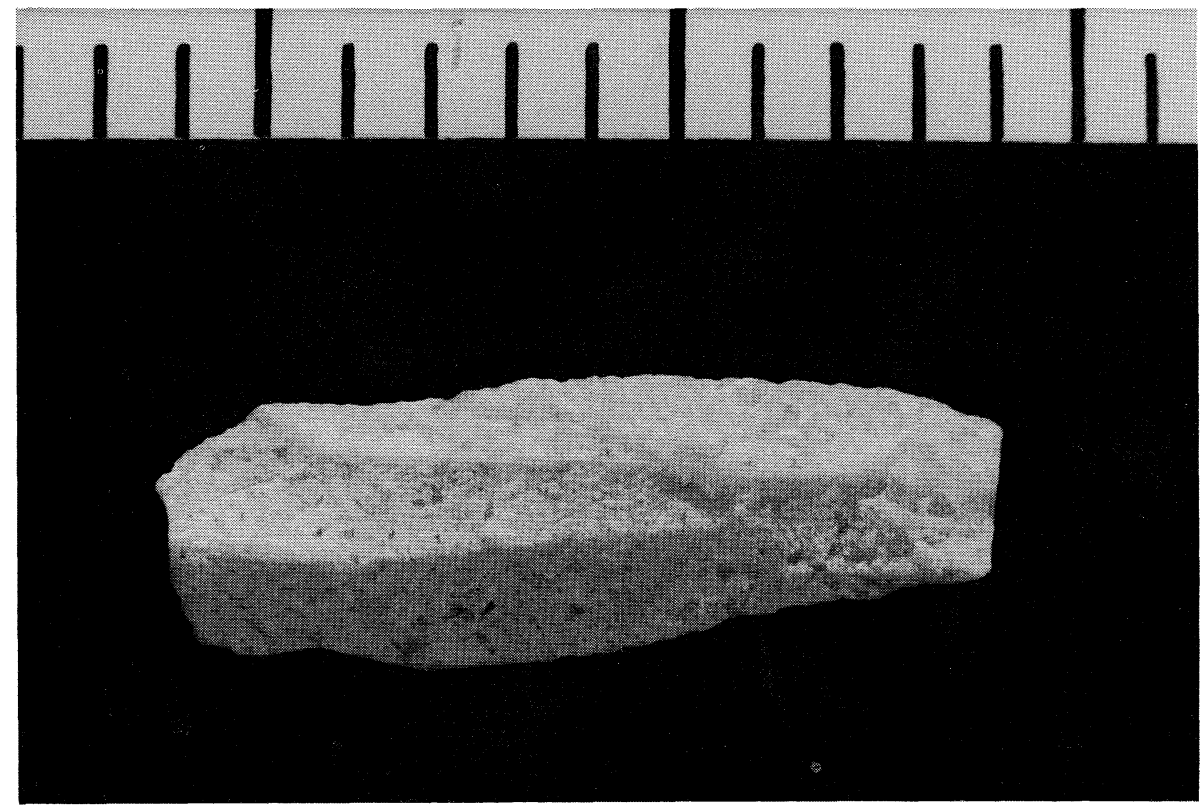

Plate 2. Artefact W-A-1 (seen from the dorsal side).

(Picture taken by B.N. STORM, The Hague, The Netherlands)

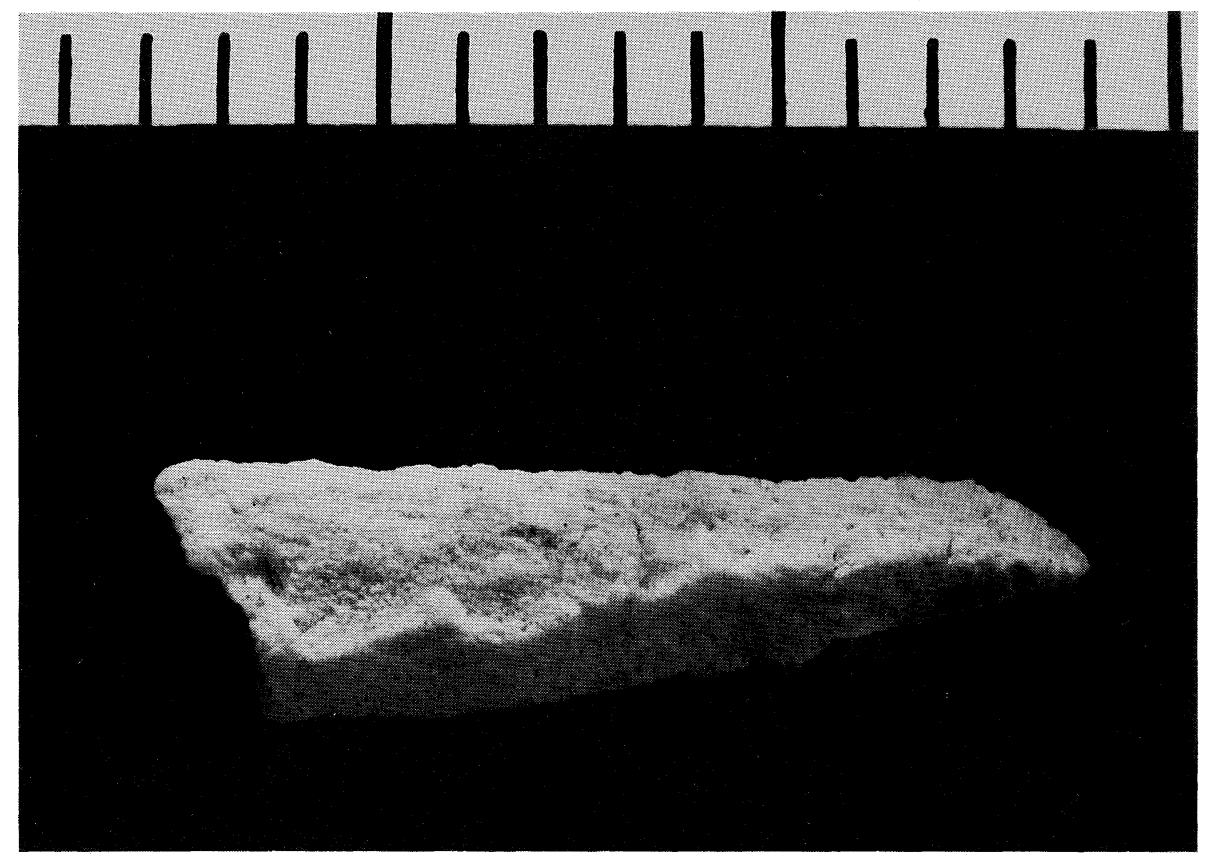

Plate 3. Artefact W-A-2 (seen from the dorsal side).

(Picture taken by B.N. STORM, The Hague, The Netherlands) 


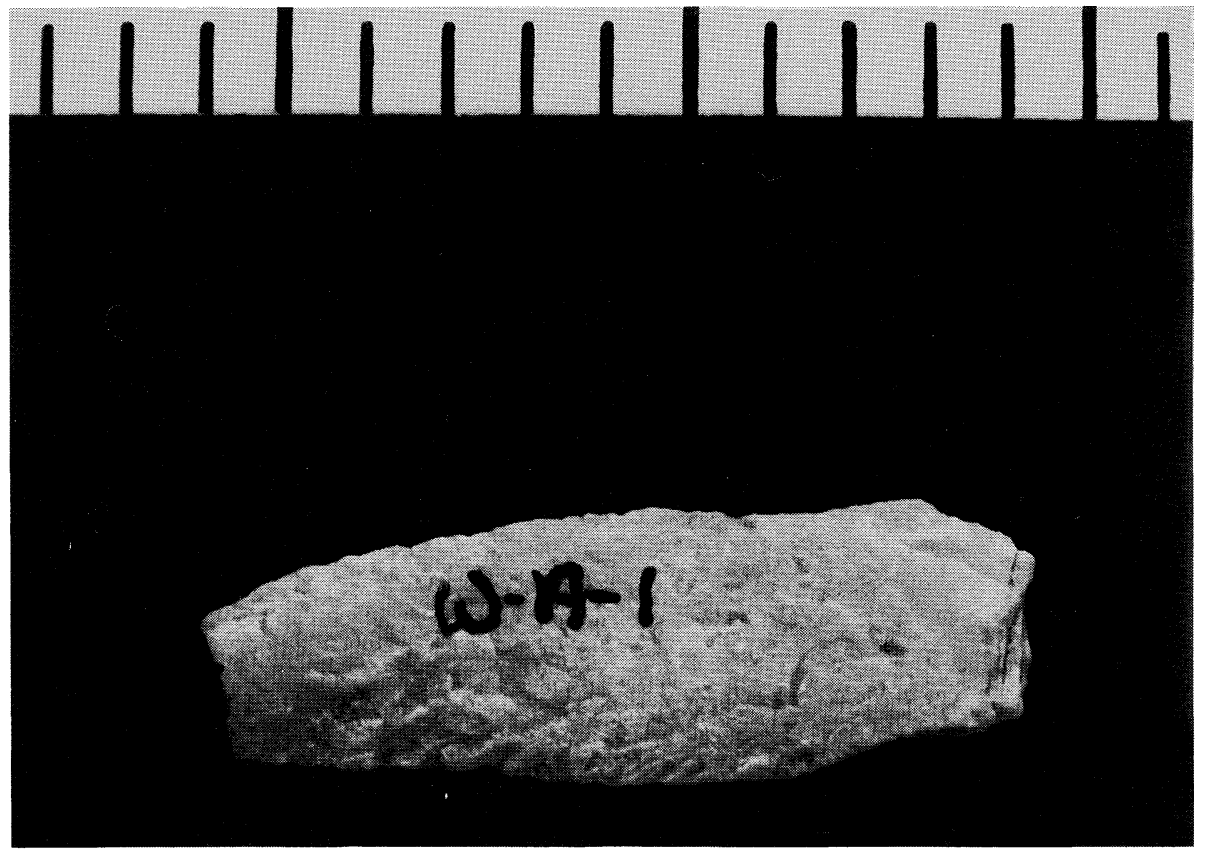

Plate 4. Artefact W-A-1 (seen from the ventral side). (Picture taken by B.N. STORM, The Netherlands)

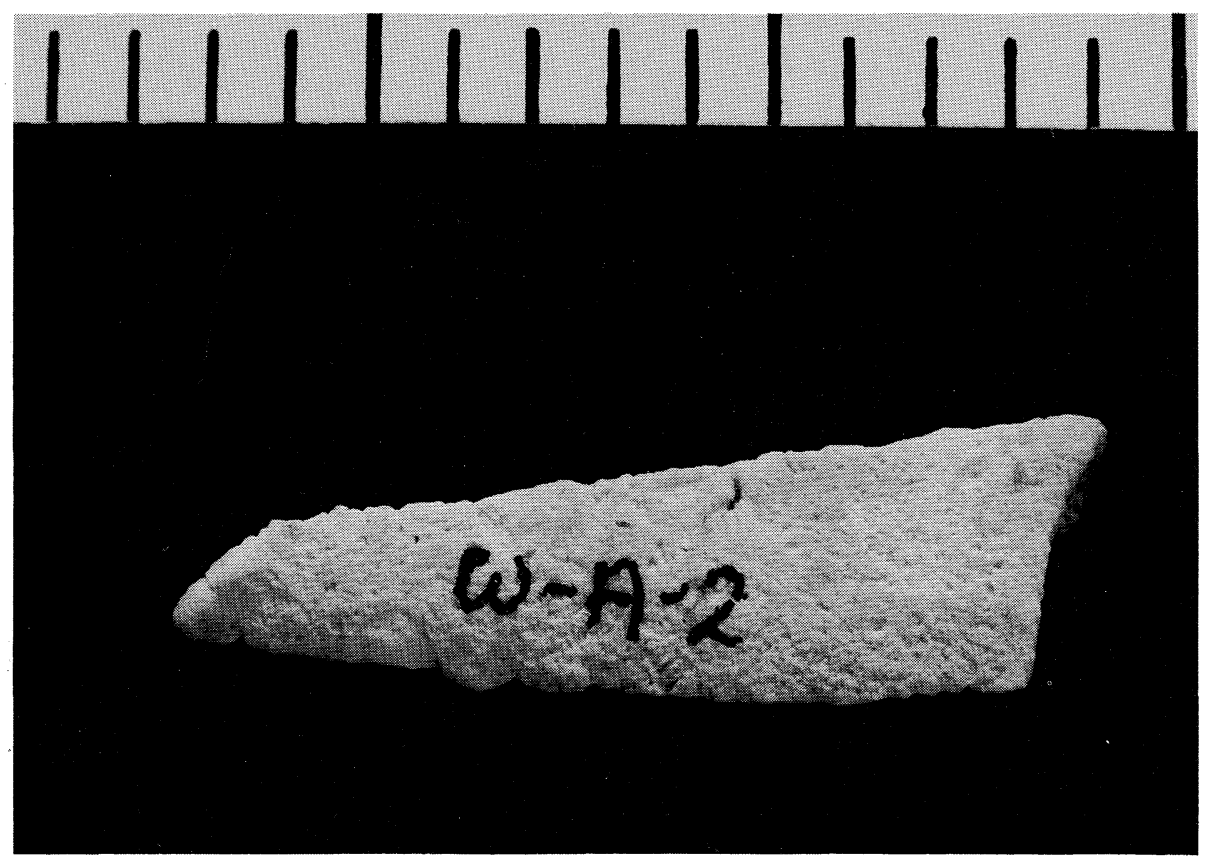

Plate 5. Artefact W-A-2 (seen from the ventral side). (Picture taken by B.N. STORM, The Netherlands) 